\title{
A Retrospective Study of Neonaticides in Shanghai from 2007 to 2013
}

\author{
Bei-Xu Li ${ }^{1}$, Yan-Chang Ge ${ }^{2,3}, \mathrm{Ai}-$ Min Xue ${ }^{1}$, Kai-Jun $\mathrm{Ma}^{2}$ and Yi-Wen Shen ${ }^{1,4^{*}}$ \\ ${ }^{1}$ Department of Forensic Medicine, School of Basic Medical Sciences, Fudan University, PR China \\ ${ }^{2}$ Shanghai Key Laboratory of Crime Scene Evidence, Institute of Forensic Science, Shanghai Public Security Bureau, PR China \\ ${ }^{3}$ Economic and Technological Development Zone (International Business District) Branch of Jiaxing Public Security Bureau, PR China \\ ${ }^{4}$ Remote Forensic Consultation Center, Collaborative Innovation Center of Judicial Civilization, China University of Political Science and Law, PR China
}

"Corresponding author: Yi-Wen Shen, Remote Forensic Consultation Center, Collaborative Innovation Center of Judicial Civilization, China University of Political Science and Law, 138 Yixueyuan Road, Xuhui District, Shanghai 200032, PR China, Tel: +86-21-54237402; E-mail: fdshenyiwen@163.com

Received date: March 13, 2017; Accepted date: June 27, 2017; Published date: June 30, 2017

Copyright: ( $2017 \mathrm{Li} \mathrm{BW}$, et al. This is an open-access article distributed under the terms of the Creative Commons Attribution License, which permits unrestricted use, distribution, and reproduction in any medium, provided the original author and source are credited.

\begin{abstract}
Neonaticide is defined as killing of a newborn within the first 24 hours of life. Neonaticide happens globally. The characteristics and motives of Chinese neonaticide are unknown. This study is committed to outline Chinese neonaticide offenders' characteristics and primary motives. Neonaticide cases in Shanghai Public Security Bureau (SPSB) were reviewed and analyzed. All offenders were domestic migrants with normal mental status. Neonaticide offenders' common characteristics such as biological mother, young age, immaturity, being unmarried, low socioeconomic status and having an unwanted pregnancy were confirmed. 18 unmarried offenders were resident in Shanghai under 2 years. Their first sexual experience occurred around coming to Shanghai. The offenses occurred under 2 years after coming to Shanghai due to the stigma of illegitimacy. 2 married offenders were resident in Shanghai over 5 years. They both already had children. They committed neonaticides due to the stigma of giving birth to a female newborn and removal of a burden. Migration, life changes and separation from original families were verified and could be seen as a main factor in the neonaticides. First sexual experience, unwanted pregnancy and neonaticide occurred in unmarried young women under this background. Unwanted baby was primary motive. Unmarried young women with low socio-economic status and recent migration who got unwanted pregnancies are more prone to commit neonaticide. Basic medical care and interventions should be extensively spread in them to improve human beings' well-beings.
\end{abstract}

Keywords Neonaticide; Unmarried offenders: Unwanted baby; Unmarried young mother; Domestic migrant

\section{Introduction}

It is a major public health problem to kill a newborn within the first 24 hours of life. This phenomenon has different names in the past, then forensic psychiatrist Phillip Resnick coined the name neonaticide which usually was committed by a biological parent and distinguished from the killing of older children (infanticide or filicide) [1,2]. It happens in many countries with different cultures and development levels, such as the US, Germany, Netherland, India, France and Austria [3-8]. Though neonaticide is usually covert and rarely appeared in the media, there is voluminous literature on neonaticide from the 18th and 19th centuries. However, there was no study focusing on Chinese neonaticides.

Biological mother, young age, immaturity, being unmarried, low socio-economic status and having an unwanted and secret pregnancy are considered as the neonaticide offenders' common characteristics by contemporary international studies [9-11]. Possible motives for neonaticide included altruism, revenge, undesirable or unwanted child, psychiatric disorders and accidentally manslaughter $[6,12]$. Postpartum depression is contributed to infanticide [13-15]. Maybe it is a reasonable interpretation for neonaticide, but the previous studies revealed that unwanted child was the main motive for neonaticide rather than postpartum depression $[4,6,12]$. Stigma of illegitimacy, stigma of giving birth of a female newborn and removal of burden were contributed to neonaticide. Stigma of baby girl seems the most common motive to commit neonaticide in India, which is even more humiliating than illegitimate child $[4,12]$. In China, the similarly populous country in Asia, son preference is also a traditional evil $[16,17]$. Female infanticide and girl abuse appeared due to family plan $[17,18]$, although a family is allowed to have two babies since 2015 . It was implied the neglect to female baby's right in previous study. Because this trend is being eliminated in China due to improvement of education and income, it is unknown whether son preference is a crucial factor in neonaticide.

The characteristics and motives of neonaticide in China are still unknown. This study is committed to outline Chinese neonaticide offenders' characteristics, find the primary motives and dig deeper reasons behind the phenomenon. Based on the findings, future interventions can be carried out to prevent neonaticide and protect the newborns' as well as the offenders' well-beings.

\section{Materials and Methods}

Shanghai Public Security Bureau (SPSB), as well as its branches, takes responsibility for public security and crime control in Shanghai, China [19]. All the unnatural deaths in Shanghai are initially reported to SPSB, thus neonaticides in its jurisdiction were handled by SPSB. This study was a retrospective review of neonaticide cases in SPSB over a 7-year period from 2007.1 to 2013.12. Cases were accepted for this study according to the following criteria: (1) corpses were found in Shanghai, and cases were handled by SPSB; (2) case investigation was closed and the offenders were sentenced; (3) manner of death was 
Page 2 of 6

definitely homicide; (4) the victims were live birth and killed within 24 hours after delivery; (5) DNA identification was done.

A total of 20 cases met the study criteria of neonaticide case. Data were extracted from these cases' autopsy archives, the initial investigations, police reports, hospital reports and interviews with family kept in SPSB. These materials were reviewed and analyzed as to (1) demographic data of the offenders, such as age at the time of the neonaticide, gender, and registered permanent residence; (2) case information; (3) offender's motive; (4) offender's mental status; (5) offender's life tracks prior to crime; (6) relationship between the offender and the victim; (7) information about offenders' sex and pregnancy; (8) victim's cause of death. Two reviewers independently extracted data from each of the cases. Disagreements between reviewers were resolved through discussions and a final consensus.

The data were presented as means-standard errors (SE) for age. Statistical analysis was given using the related programs in Microsoft Excel 2013.
This retrospective study was based on the forensic autopsy cases archives. It was approved by both Shanghai Public Security Bureau Ethics Committee and Fudan University Ethics Committee. The written informed consent was given by decedent's next of kin, who was told that the investigation information might be used in the scientific research when the autopsy was taken. All the archives were anonymized and de-identified prior to analysis.

\section{Results}

Each neonaticide was committed by single offender at the temporary residence. All the 20 offenders were domestic migrants, and their mental status was normal. None of the victims' biological mothers obtained regular antenatal checks. Of all the 20 offenders, 18 offenders were unmarried. All the 20 victims were live birth. The characteristics of unmarried and married offenders were shown in Table 1.

\begin{tabular}{|c|c|c|c|}
\hline & Classification & Unmarried $(n=18)$ & Married $(n=2)$ \\
\hline \multirow{2}{*}{ Relationship to victim } & Biological mother & 18 & 1 (female) \\
\hline & Biological father & & 1 (male) \\
\hline \multirow{3}{*}{ Duration in Shanghai } & $\leq 2$ years & 14 & \\
\hline & $2-5$ years & 4 & \\
\hline & $>5$ years & & 2 \\
\hline \multirow{4}{*}{ Interval between first sexual encounter and entering Shanghai } & Within 1 year before entering Shanghai & 5 & \\
\hline & The year entering Shanghai & 7 & 1 (female) \\
\hline & Within 1 year after entering Shanghai & 6 & \\
\hline & Unknown or unrecorded & & 1 (male) \\
\hline \multirow{3}{*}{ First sexual encounter after coming of age } & No & 12 & \\
\hline & Yes & 6 & 1 (female) \\
\hline & Unknown or unrecorded & & 1 (male) \\
\hline \multirow{4}{*}{ Interval between first sexual encounter and neonaticide } & $\leq 2$ years & 14 & \\
\hline & $2-5$ years & 4 & \\
\hline & $>5$ years & & 1 (female) \\
\hline & Unknown or unrecorded & & 1 (male) \\
\hline \multirow{3}{*}{ Education status of offenders } & Middle school & 14 & 2 \\
\hline & High school & 3 & \\
\hline & University & 1 & \\
\hline \multirow{3}{*}{ Income } & Low & 12 & 2 \\
\hline & Middle & 3 & \\
\hline & No income & 3 & \\
\hline \multirow{2}{*}{ Only child in original family } & No & 13 & 2 \\
\hline & Yes & 5 & \\
\hline
\end{tabular}


Citation: $\quad$ Li BX, Ge YC, Xue AM, Ma KJ, Shen YW (2017) A Retrospective Study of Neonaticides in Shanghai from 2007 to 2013. J Forensic Res

Page 3 of 6

\begin{tabular}{|c|c|c|c|}
\hline \multirow{2}{*}{ Primipara or multipara } & Primipara & 18 & \\
\hline & Multipara & & 2 \\
\hline \multirow{4}{*}{ When knowing pregnancy } & First trimester & 3 & 1 (female) \\
\hline & Second trimester & 12 & \\
\hline & Third trimester & 3 & \\
\hline & Unknown or unrecorded & & 1 (male) \\
\hline \multirow{2}{*}{ Contraceptive knowledge } & No & 18 & \\
\hline & Have & & 2 \\
\hline \multirow{4}{*}{ Quantity of sex partner } & 1 & 11 & \\
\hline & 2 & 3 & 1 (female) \\
\hline & 3 & 2 & \\
\hline & Unknown or unrecorded & 2 & 1 (male) \\
\hline \multirow{2}{*}{ Unwanted pregnancy } & unwanted & 18 & 1 (male) \\
\hline & intended & & 1 (female) \\
\hline \multirow{2}{*}{ Offender's parents know the pregnancy } & No & 18 & \\
\hline & Yes & & 2 \\
\hline \multirow{4}{*}{ Cause of death } & Manual strangulation & 10 & 2 \\
\hline & Smothering & 4 & \\
\hline & Throw from height & 2 & \\
\hline & Drowning & 2 & \\
\hline \multirow{3}{*}{ Motive } & Stigma of illegitimacy & 18 & \\
\hline & Removal of burden, economic pressure & & 1(male) \\
\hline & Hopeless, stigma of giving birth of a female newborn & & 1 (female) \\
\hline \multirow{2}{*}{ Location of delivery } & Temporary residence & 18 & \\
\hline & Hospital or clinic & & 2 \\
\hline \multirow{2}{*}{ Gender of victim } & Male & 10 & \\
\hline & Female & 8 & 2 \\
\hline
\end{tabular}

Table 1: Characteristics and motives of neonaticides in Shanghai (2007-2013).

\section{Unmarried Offenders}

The 18 unmarried offenders could be outlined as one character. They were young and unmarried primiparas. They were victims' biological mothers. They had no contraceptive knowledge and got unwanted pregnancies. Their parents did not know their pregnancies. Their average age at the time of the neonaticide was $19.4 \pm 1.9$ yearold, with 2 offenders under 18 year-old (Table 2).

Most unmarried offenders were poorly educated and only had low income. More than a half of unmarried offenders had only one sexual partner. 13 offenders had siblings, they were not the only child in family. 15 offenders did not know the pregnancies before the second trimester. 14 offenders were resident in Shanghai no more than 2 years. 14 offenders killed the newborns no more than 2 years after their first sexual encounter.

14 offenders killed the newborns no more than 2 years after coming to Shanghai. Their first sexual experience occurred from 1 year before coming to Shanghai to 1 year after coming to Shanghai. They gave births in their temporary residences. And 10 offenders manually strangulated their babies. They all committed neonaticides due to stigma of illegitimacy. The male to female ratio of victims were 10:8. 


\begin{tabular}{|c|c|c|c|}
\hline Case & Age at the neonaticide (year-old) & Duration in Shanghai (years) & Age of first sexual encounter (year-old) \\
\hline 1 & 18 & 2 & 17 \\
\hline 2 & 21 & 3 & 19 \\
\hline 3 & 19 & 1 & 17 \\
\hline 4 & 16 & 1 & 15 \\
\hline 5 & 20 & 2 & 19 \\
\hline 6 & 19 & 2 & 17 \\
\hline 7 married female & 29 & 8 & 21 \\
\hline 8 & 18 & 1.5 & 17 \\
\hline 9 & 22 & 4 & 19 \\
\hline 10 married male & 25 & 6 & \\
\hline 11 & 21 & 3 & 17 \\
\hline 12 & 22 & 2 & 20 \\
\hline 13 & 20 & 2 & 18 \\
\hline 14 & 18 & 2 & 16 \\
\hline 15 & 19 & 1.5 & 17 \\
\hline 16 & 23 & 4 & 18 \\
\hline 17 & 18 & 2 & 17 \\
\hline 18 & 19 & 2 & 16 \\
\hline 19 & 17 & 1 & 16 \\
\hline 20 & 19 & 2 & 17 \\
\hline
\end{tabular}

Table 2: Time of the neonaticide, duration in Shanghai and first sexual encounter.

\section{Married Offenders}

One newborn was killed by her 29 year-old biological mother. She already had 2 daughters. She had contraceptive knowledge and got intended pregnancy. The other newborn was killed by her 25 year-old biological father. He already had 1 daughter. He had contraceptive knowledge, but his wife got unwanted pregnancy. They were both poorly educated and low-income.

The female offender had 2 sexual partners, but quantity of the male offender's sexual partners was unknown or unrecorded. They both had siblings. The female offender knew the pregnancy in the first trimester. They were both resident in Shanghai more than 5 years. She killed the newborn more than 5 years after coming to Shanghai. Her first sexual experience also occurred in the year coming to Shanghai.

The 2 victims' mothers gave births in hospital or clinic. The 2 victims were manually strangulated. The female offender committed neonaticide due to the stigma of giving birth to a female newborn, and she felt hopeless. The biological father committed neonaticide due to economic pressure and removal of a burden. The victims were both females.

\section{Discussion}

Neonaticide offenders' common characteristics in contemporary international studies such as biological mother, young age, immaturity, being unmarried, low socio-economic status and having an unwanted pregnancy are confirmed in this study [9-11]. They usually did not know the pregnancy until the second trimester due to young age and lack of knowledge and experience. Their parents usually did not know pregnancies, possibly due to intended hiding. They gave birth out of hospital, and did not seek antenatal care [20-22]. Besides, it was showed that all the offenders were young domestic migrants in this study.

Shanghai has a population over 24 million, which are composed by 14 million locals and 10 million domestic migrants. The births among the 24 million inhabitants are 182 thousand per year, while the terminations are 123 thousand per year. The births among the 14 million locals are 104 thousand per year, while the terminations are 115 thousand per year. The births among the 10 million domestic migrants are 78 thousand per year, while the terminations are 8 thousand per year. A large number of migrants are low-income with poor education, consisting with this study's findings. They typically have no medical insurance, and are often involved in unnatural deaths such as illegal medical practice deaths [23-27]. Aloneness, separation 
from their original families and financial weakness make them mentally vulnerable.

In this study, changes in living environment and separation from their original families were verified and could be seen as a main factor in the neonaticides. Social environment is seen as a relevant factor of neonaticide [28]. To assess the influence of changes in living environment and separation from their original families, time of entering Shanghai, time of first sexual experience and time of neonaticide were investigated.

Most unmarried offenders committed neonaticides within 2 years after their first sexual encounter, and within 2 years after entering Shanghai. Consideration of the gestation period, they got unwanted pregnancies only approximately 1 year after first sexual encounter, and entering Shanghai. They did not know the pregnancy before the second trimester. This was consisted with their lack of contraceptive knowledge [29]. Entering Shanghai is related with first sexual encounter and neonaticde in the unmarried young women. Without the regulation of original families, the young unmarried offenders were vulnerable to get unwanted pregnancies. Besides, though one family usually has only one child according to Chinese family planning policy, 15 out of 20 offenders had siblings in their original families. Multiple children may aggravate lack of parental regulation.

All unmarried offenders whose motives were mainly stigma of illegitimacy had their first sexual experience around coming to Shanghai, and more than half of them had first sexual experience before they came of age (18 year-old in China). Before entering Shanghai, young women were intranquil, worried and excited on the unknown future life in Shanghai. After entering Shanghai, aloneness, helplessness, separation from their original families and financial weakness made them eager for emotional comforts. Their first sexual experience may occur under this background.

The married offenders were resident in Shanghai more than 5 years. Although they should adapt to living in Shanghai and be mature, they were poorly educated and low-income workers. It can be inferred that their offences were related to the low socio-economic status.

Possible motives for neonaticide included altruism, revenge, undesirable or unwanted child, psychiatric disorders and accidentally manslaughter $[6,12]$. In this study, the unmarried offenses were due to the stigma of illegitimacy, the married female offender's motive was hopeless and stigma of giving birth of a female newborn, and the married male offender's motive was financial stress and removal of a burden. The primary motive in all 20 cases was that the child was undesirable or unwanted, which was similar to the previous study in US [6]. Although previous studies showed slight tendency of female infanticide and discrimination in care practices for girls in China, only 1 offender killed her newborn because of the newborn's gender [19]. The female newborn was the third child of the offender, who already had 2 daughters. Three straight daughters were not the offender's expectation, and she cannot tolerate the stigma of a third girl. Even this pregnancy was intended, she killed her baby. She and two Indian women were in the same situation [4]. The stigma of female gender is much more humiliating than illegitimacy in India [4]. According to the results from this study, the stigma of female gender in Shanghai, China is slighter than illegitimacy, and not as awful as India. The Italian study confirmed that neonaticide was to increase the biological fitness of the mother by eliminating an unwanted newborn and saving resources for future offspring born in better conditions, and thus neonaticide was clearly distinct from infanticide and filicide and therefore should be approached, prevented, and judged differently [30]. However, our results showed difference, the offenders just set their eyes on shortterm personal gain without far-sighted consideration.

Besides, some offenders committed neonaticide, because they were unsure of the paternity of the victim due to their multiple sexual relationships or the pregnancy was the result of an extramarital affair [6]. Quantity of offender's sex partners was investigated in this study. Though 6 offenders had more than 2 sex partners, none worried about the uncertainty of the paternity of the victim. Multiple sexual relationships were not contributed to neonaticide in this study.

There are some limitations in this study. Though each neonaticide was committed by single offender, but it is unknown whether anyone accompanied the puerpera when delivery. Victims were vulnerable to kill without tools. The truth is hard to restore. Whether the neonaticide was the result of offenders' private sudden decision or multiplayer conspiracy is unknown.

The main limitation is that whether the offenders were postpartum depression was unknown. Infanticides are often assumed to be linked to postpartum depression or psychosis, or other mental illnesses such as Munchausen by proxy syndrome [12-15]. The 20 offenders' mental status was normal based on the materials we used. The offenses were committed within 24 hours of birth, it is impossible to diagnose postpartum depression in such short time, and it is hard to see a psychiatrist in such short time. Only offenders' pregnancy psychosocial status and ordinary mental status can be used to assess their mental status at committing offense. Chinese are not used to visiting a psychiatric disorder specialist, and their medical records are not as integral and detailed as those in US or EU, so some information was missed, unrecorded or unknown [31]. According to the offenders' confession, their motives were verified exclusively, which were undesirable or unwanted child due to personal gain. Postpartum depression may not be involved in neonaticide.

\section{Conclusion}

Unmarried young women with unwanted pregnancy, especially with low socio-economic status and recent migration, are more prone to commit neonaticide. Neonaticide in China has its own characteristic. Migration can be seen as a relevant factor of neonaticide. Interventions should be taken in young migrant female workers in Shanghai to prevent these tragedies. Basic medical care and contraceptive knowledge should be extensively spread in young migrant female workers to improve human beings' well-beings.

\section{Acknowledgement}

This study is supported by Shanghai Key Laboratory of Crime Scene Evidence, Institute of Forensic Science, Shanghai Public Security Bureau (2015XCWZK01 and 2017XCWZK17); Funds for Youth in Department of Forensic Medicine, School of Basic Medical Sciences, Fudan University (FY2014-01); and Remote Forensic Consultation Center, Collaborative Innovation Center of Judicial Civilization, China University of Political Science and Law. The funders had no role in study design, data collection and analysis, decision to publish, or preparation of the manuscript.

\section{References}

1. Resnick PJ (1970) Murder of the newborn: A psychiatric review of neonaticide. Am J Psychiatry 126: 1414-1420. 
2. Resnick PJ (1969) Child murder by parents: A psychiatric review of filicide. Am J Psychiatry 126: 325-334.

3. Makhlouf F, Rambaud C (2014) Child homicide and neglect in France: 1991-2008. Child Abuse Negl 38: 37-41.

4. Mishra K, Ramachandran S, Kumar A, Tiwari S, Chopra N, et al. (2014) Neonaticide in India and the stigma of female gender: Report of two cases. Paediatr Int Child Health 34: 224-226.

5. Schulte B, Rothschild MA, Vennemann M, Banaschak S (2013) Examination of (suspected) neonaticides in Germany: A critical report on a comparative study. Int J Legal Med 127: 621-625.

6. Shelton JL, Muirhead Y, Canning KE (2010) Ambivalence toward mothers who kill: An examination of 45 U.S. cases of maternal neonaticide. Behav Sci Law 28: 812-831.

7. Sieswerda-Hoogendoorn T, Soerdjbalie-Maikoe V, Maes A, van Rijn RR (2013) The value of post-mortem CT in neonaticide in case of severe decomposition: Description of 12 cases. Forensic Sci Int 233: 298-303.

8. Klier CM, Grylli C, Amon S, Fiala C, Weizmann-Henelius G, et al. (2013) Is the introduction of anonymous delivery associated with a reduction of high neonaticide rates in Austria? A retrospective study. BJOG 120: 428-434.

9. Lee AC, Li CH, Kwong NS, So KT (2006) Neonaticide, newborn abandonment, and denial of pregnancy--newborn victimisation associated with unwanted motherhood. Hong Kong Med J 12: 61-64.

10. Mendlowicz MV, Rapaport MH, Mecler K, Golshan S, Moraes TM (1998) A case-control study on the socio-demographic characteristics of 53 neonaticidal mothers. Int J Law Psychiatry 21: 209-219.

11. Putkonen H, Weizmann-Henelius G, Collander J, Santtila P, Eronen M (2007) Neonaticides may be more preventable and heterogeneous than previously thought - neonaticides in Finland 1980-2000. Arch Womens Ment Health 10: 15-23.

12. Gavin H (2014) Reasons for female neonaticide in India. Paediatr Int Child Health 34: 153.

13. Porter T, Gavin H (2010) Infanticide and neonaticide: A review of 40 years of research literature on incidence and causes. Trauma Violence Abuse 11: 99-112.

14. Kauppi A, Kumpulainen K, Vanamo T, Merikanto J, Karkola K (2008) Maternal depression and filicide-case study of ten mothers. Arch Womens Ment Health 11: 201-206.

15. Babu GN, Subbakrishna DK, Chandra PS (2008) Prevalence and correlates of suicidality among Indian women with post-partum psychosis in an inpatient setting. Aust N Z J Psychiatry 42: 976-980.

16. Hesketh T, Xing ZW (2006) Abnormal sex ratios in human populations: Causes and consequences. Proc Natl Acad Sci U S A 103: 13271-13275.
17. Miller BD (2001) Female-selective abortion in Asia: Patterns, policies, and debates. Am Anthropol 103: 1083-1095.

18. Hesketh T, Zhu WX (1997) Health in China - The one child family policy: The good, the bad, and the ugly. British Medical Journal 314: 1685-1687.

19. He M, Li WC, Sun DM, Ma KJ, Zhao ZQ, et al. (2014) Epitome of China's unnatural deaths: A historically retrospective study of forensic autopsy cases in Shanghai Public Security Bureau from 1990 to 1999. Am J Forensic Med Pathol 35: 218-221.

20. Craig M (2004) Perinatal risk factors for neonaticide and infant homicide: Can we identify those at risk? J R Soc Med 97: 57-61.

21. Friedman SH, Resnick PJ (2009) Neonaticide: Phenomenology and considerations for prevention. Int J Law Psychiatry 32: 43-47.

22. Saunders E (1989) Neonaticides following "secret" pregnancies: Seven case reports. Public Health Rep 104: 368-372.

23. Shaokang Z, Zhenwei S, Blas E (2002) Economic transition and maternal health care for internal migrants in Shanghai, China. Health Policy Plan 17 Suppl: 47-55.

24. Shi Y, Ji Y, Sun J, Wang Y, Sun X, et al. (2012) Lack of health risk awareness in low-income Chinese youth migrants: Assessment and associated factors. Environ Health Prev Med 17: 385-393.

25. Wang Y, Cochran C, Xu P, Shen JJ, Zeng G, et al. (2014) Acquired immunodeficiency syndrome/human immunodeficiency virus knowledge, attitudes, and practices, and use of healthcare services among rural migrants: A cross-sectional study in China. BMC Public Health 14: 158.

26. Zhao Q, Huang ZJ, Yang S, Pan J, Smith B, et al. (2012) The utilization of antenatal care among rural-to-urban migrant women in Shanghai: A hospital-based cross-sectional study. BMC Public Health 12: 1012.

27. He M, Fang YX, Lin JY, Ma KJ, Li BX (2015) Unnatural deaths in Shanghai from 2000 to 2009: A retrospective study of forensic autopsy cases at the Shanghai Public Security Bureau. PLoS One 10: e0131309.

28. Amon S, Putkonen H, Weizmann-Henelius G, Almiron MP, Formann AK, et al. (2012) Potential predictors in neonaticide: The impact of the circumstances of pregnancy. Arch Womens Ment Health 15: 167-174.

29. Platt LM (2014) Preventing neonaticide by early detection and intervention in student pregnancy. NASN Sch Nurse 29: 304-308.

30. Camperio Ciani AS, Fontanesi L (2012) Mothers who kill their offspring: Testing evolutionary hypothesis in a 110-case Italian sample. Child Abuse Negl 36: 519-527.

31. Fang YX, He M, Lin JY, Ma KJ, Zhao H, et al. (2015) Suicidal drownings with psychiatric disorders in Shanghai: A retrospective study from 2010.1 to 2014.6. PLoS One 10: e0121050. 